\section{Império das \\ palavras}

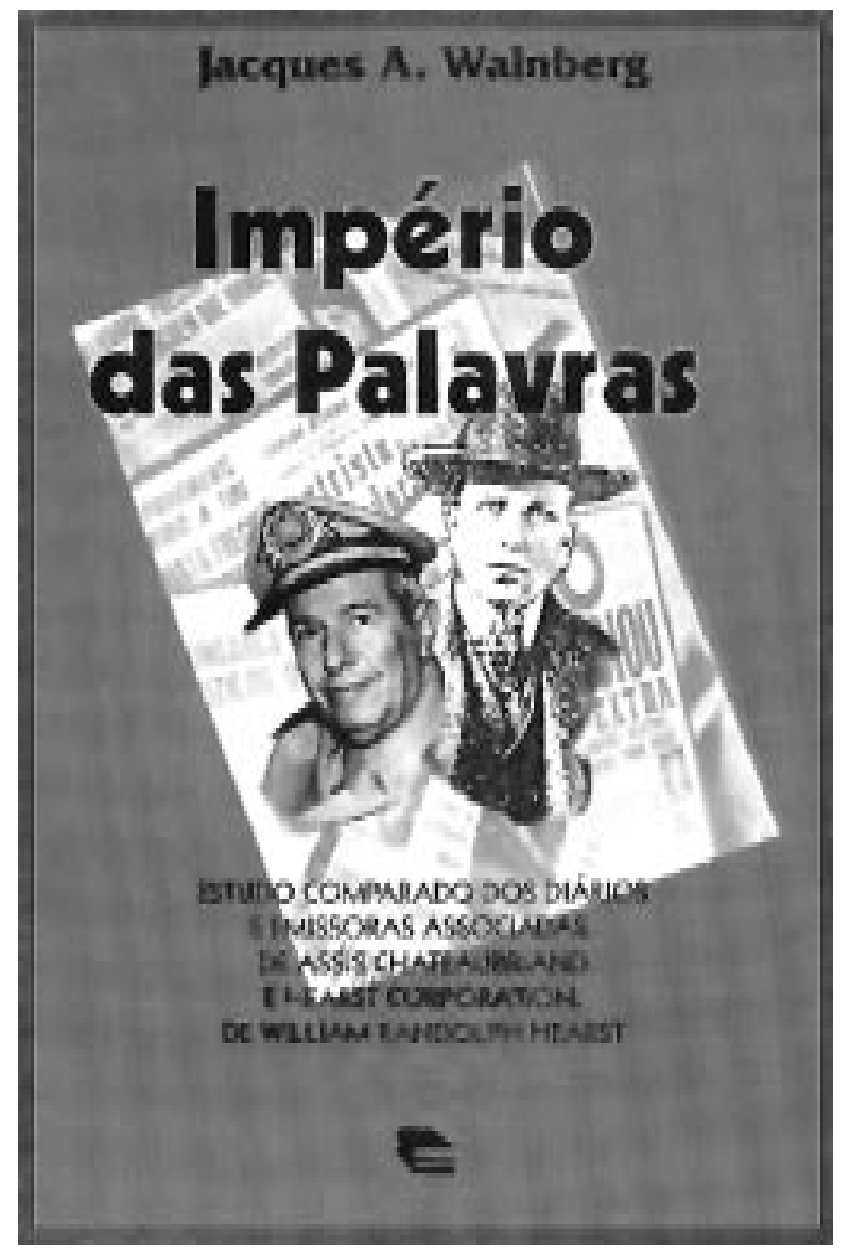

Antonio Hohlfeldt

Dr. Prof. da FAMECOS/PUCRS

Coord. do Programa de Pós-grad. da FAMECOS/PUCRS
O MÉTODO DA PESQUISA comparada é extremamente útil para que se possa compreender, com maior facilidade e objetividade, determinados acontecimentos. Tal foi, por certo, a perspectiva adotada pelo professor Jacques Wainberg, ao escrever Império das palavras, sua tese de doutorado, em que aproxima o império das comunicações do norte-americano William Randolph Hearst e o do brasileiro Assis Chateaubriand, processos em tudo semelhantes, ainda que ocorrendo em décadas, espaços e culturas absolutamente diversos.

O livro, como ocorre com as teses de dutorado, é rigoroso em sua organização e desenvolvimento, guardando sempre a perspectiva comparativista: no primeiro grande capítulo, desenha-se o contexto histórico, econômico, político e cultural de cada país, o take off norte-americano da década dos oitenta, no século passado, e o letárgico despertar brasileiro dos anos 20 deste século.

Depois, aborda-se a questão ideológica do que se poderia denominar da doutrina que cada um dos dois pioneiros desenvolveu e fixou em sua sociedade, entre seus colaboradores e, enfim, junto a seus adeptos e cultores, ao que Wainberg denominará de hearstianismo e chateaubrianismo, respectivamente.

Passa-se, então, à história propriamente dita de cada um dos dois impérios, ocupando-se três imensos capítulos, respondendo, cada qual, por um período semelhante que aquelas organizações experimentaram, segundo o autor, o nascimento e a expansão, a estagnação e, enfim, o ocaso e o renascimento. A simples leitura evidencia serem, na verdade, cinco momentos, os dois primeiros formando um conjunto dicotômico, da mesma forma que os dois últimos, ficando apenas a estagnação com uma só perspectiva de abordagem.

É a ênfase sobre o chamado jornalismo de editor o que Jacques Wainberg vai desta- 
car desde logo, para poder explicar o duplo fenômeno ocorrido nos Estados Unidos e no Brasil. Opor-se-ia este jornalismo, pois, ao hoje denominado jornalismo de leitor e teria sido esta evolução, portanto, genericamente, o motivo pelo qual os dois grandes grupos acabaram por sucumbir. $\mathrm{Na}$ verdade, as coisas não são assim tão simples. Jacques Wainberg, que é também historiador, dá a necessária atenção à própria biografia dos pioneiros, e consegue entender que, efetivamente, houve uma simbiose entre o contexto histórico-cultural-econômico-político com a biografia dos pioneiros, de maneira que foram também importantes as características psicológicas dessas personagens e a visão de mundo, inovadora, que elas apresentaram. Tanto isso é verdade que, quando doentes e depois falecidos, seus impérios se dissolveram. Deve-se, pois, levar em conta, aí, o fato de que, ao enfrentarem, derrotarem e ultrapassarem diferentes adversários, Hearst e Chateaubriand terminaram por construir também seus futuros oponentes. E no processo histórico, as conquistas por eles alcançadas, ao gerarem certo sentimento de climax atingido, permitiram que outros grupos se preparassem para enfrentá-los e, por sua vez, vencê-los.

O processo, portanto, é profundamente complexo, e é esta complexidade que Jacques Wainberg consegue surpreender, graças à perspectiva comparativista que adotou. Guardadas as proporções, sabendose que a história não se repete, indica-nos o autor terem ocorrido fenômenos semelhantes, ainda que díspares e distantes no tempo, no espaço e na cultura.

Pesquisa rigorosa e extensa, qualificação da análise dos dados levantados, o volume que Jacques Wainberg nos apresenta só traz um pecado editorial irritante, às vezes: a falta de uma revisão acurada que evitasse erros de português e de citações bibliográficas. Da mesma maneira, algumas repetições poderiam, quem sabe, ter sido retiradas, tornando o texto um pouco mais fluente. Tiradas estas questões menores, contudo, é simplesmente brilhante o traba- lho de Jacques Wainberg, que nos permite, com esta obra, compreender não apenas o fenômeno Chatô quanto, por exemplo, hoje em dia, a experiência do Grupo Globo de Roberto Marinho.

De fato, se "os Diários e Emissoras Associadas constituíram uma das evidências mais contundentes da modernidade brasileira" (p. 277), por ter sido um produto original na pasmaceira brasileira da década de 20 do atual século, dependeu, na verdade, da perspectiva liberalista, que ingressara no país no final do século anterior, da corrente nativista trazida pelo Modernismo, e do culto pelo nacional, que se ampliaria ainda com o Estado Novo, segundo Jacques Wainberg. Chateaubriand como William Hearst, contudo, fizeram mais do que simples conglomerados de comunicação: ambos constituíram uma obra política colossal, claramente amoral, quando não imoral em seus relacionamentos, mas que, ainda hoje, continua causando expressões de admiração e reconhecimento. Jacques Wainberg, apesar de seu espírito crítico de análise não foge a este jargão, o que, enfim, não é nenhum pecado. Duvido que se consiga estudar alguma coisa que não nos desperte interesse ou emoção. Trata-se, por isso mesmo, de livro imperdível, porque não faz biografia personalista, mas estuda, com lucidez, um período de duas histórias nacionais cujos reflexos ainda hoje continuam exercendo influência em nossas vidas.

A destacar, ainda, os anexos do volume, em especial o último, com uma síntese de datas dos grandes episódios da história política e das comunicações em nosso país .

\section{Império das Palavras}

Jacques Wainberg. Porto Alegre: Edipucrs, 1997, 311 páginas. 